\title{
REGIONAL BENEFITS OF SERVITIZATION PROCESSES: EVIDENCE FROM THE WIND-TO-ENERGY INDUSTRY
}

\begin{abstract}
By studying servitization processes and service competencies in the wind-to-energy industry in European regions, this paper provides a framework for territorial servitization. The framework resonates with the concepts of knowledge-intensive business services (KIBS) and industry life cycles, and its elements can be embedded into concepts of regional development (e.g. lead-market models, sustainability transitions, territorial innovation models). The framework suggests that regions benefit from servitization processes via the interplay of generating employment opportunities, enabling an efficient allocation of technology resources, opening up new markets, strengthening territorial competitiveness, raising the odds of securing employment in the consolidation period, and enabling technological leaps.
\end{abstract}

Keywords: territorial servitization; wind energy; industry lifecycle; European regions;

JEL codes: P48, O18, L94 


\section{REGIONAL BENEFITS OF SERVITIZATION PROCESSES: EVIDENCE FROM THE WIND-TO-ENERGY INDUSTRY}

\section{INTRODUCTION}

To sustain competitive advantages throughout the industry life cycle, manufacturing companies can develop service competencies for providing advanced (knowledgeintensive) services (Baines et al., 2017; Gallouj, 2002). The literature phrases this as servitization, which refers to a manufacturing industry's shift from products to services. Arguably, not only individual companies benefit from service competencies (Fang, Palmatier, \& Steenkamp, 2008; Neely, 2008) but also the focal territories in which

these companies and manufacturing industries operate (Vendrell-Herrero \& Wilson, 2017). Territorial servitization is a newly emerging theme within the growing domain of servitization research (Baines et al., 2017; Lafuente, Vaillant, \& Vendrell-Herrero, 2017). This notion of territorial servitization builds on established concepts of knowledge-intensive business services (KIBS) (Gallouj, 2002; den Hertog, 2000) and the spatial configuration of competencies (Stam, 2007).

The KIBS concept suggests that service activities lead to competencies, which enhance the resilience of the local manufacturing industry (Kamp \& Ruiz de Apodaca, 2017; Lafuente et al., 2017; Menzel \& Fornahl, 2009) and strengthen competitiveness, economic growth, and employment (Muller \& Zenker, 2001). Accordingly, servitization leads to service competencies. These service competencies become locational assets, which advance the configuration of competencies in geographical regions (focal territories) (Lafuente et al., 2017).

However, previous research lacks a sufficient framework to explain mechanisms of how territories (regions) benefit from service competencies along the industry life cycle. In the present study, we answer the research question: How do 
regions benefit during the industry life cycle from service competencies built through servitization processes?

To answer this question, we study servitization processes and service competencies in the wind-to-energy (W2E) industry. We collected data through a qualitative approach in the W2E industry in European regions such as Lower Saxony, Mecklenburg-Western Pomerania (Germany), Midtjylland (Denmark), Basque country and Navarra (Spain). The W2E industry in these regions has been subject to gradual, long-term servitization processes, which have changed the territorial competence configuration. These competencies indicate how regions benefit from servitization processes.

To advance research in this manner, the present study makes deductions from the servitization literature to describe how the service competencies may lead to regional benefits. Accordingly, the article is organized as follows. In the next section, the literature is discussed. Afterwards, the methodology and findings in terms of regional benefits are described. These benefits inform a framework for territorial servitization. The article continues by discussing how existing concepts of regional economic development (e.g. sustainability transitions, lead-market model, industrial districts, entrepreneurial role model, mergers \& acquisitions for regional development) can be connected to the framework on territorial servitization.

\section{THEORETICAL BACKGROUND}

Servitization is about offering bundles of goods, services, support, self-service and knowledge in order to add value to products (Vandermerwe \& Rada, 1988). It is considered as a strategic response when manufacturing companies have reached the maturity phase in their industry life cycle in terms of increasing competition, stagnating markets, and eroding margins, which altogether make it difficult to sustain competitive 
advantages. Servitization also offers benefits in the industry formation and growth phase (Cusumano, Kahl, \& Suarez, 2015). Servitization processes are conceptualized as the specific direction of extending the service offerings from basic to advanced services. Accordingly, we consider servitization processes as implementing various service strategies in manufacturing companies. These service strategies entail the extension of various service offerings (Baines et al., 2017; Kowalkowski et al., 2015).

Extending service offerings requires service competencies along the entire value chain (e.g. research \& development, logistics, consulting, operation \& maintenance, outcome-based service competencies, etc.) (Davies, 2004; Saul \& Gebauer, 2018). In addition, these service competencies make it possible to progressively understand the customer's complex operational and strategic needs. These insights strengthen innovativeness in terms of converting them into new products, services, and solutions (Storbacka, 2011; Visnjic Kastalli \& Van Looy, 2013). Such competencies are knowledge-intensive, relatively intangible, difficult to imitate and, therefore, make 'catching up' more difficult for competitors (Matthyssens \& Vandenbempt, 2008). Service competencies also generally strengthen the financial position of the firm (Oliva \& Kallenberg, 2003; Neely, 2008; Eggert, Hogreve, Ulaga, \& Muenkhoff, 2011; Fang et al., 2008).

Such benefits are not restricted to single manufacturing companies but extend to the region in which the entire manufacturing industry is located. Service competencies in a single company may spill over and interact with competencies of other firms (e.g. component suppliers, customers, and providers of KIBS such as IT, logistics, and/or consulting services) and, finally, change the configuration of competencies in regions. This basic argument resonates with the concept of KIBS (e.g. R\&D, consulting, and/or IT outsourcing services), which distinguishes between service and manufacturing companies (Strambach, 2008). KIBS strengthen the 
competitiveness of an industry in a certain territory, while at the same time competitiveness boosts KIBS and facilitates growth and resilience of the local manufacturing industry (Gallouj, 2002; den Hertog, 2000).

Servitization also leads to knowledge-intensive services being provided by the manufacturing industry itself. Accordingly, the extension of services in manufacturing companies and industries leads to service competencies, which strengthen production and employment in the specific geographical region (Kamp \& Ruiz de Apodaca, 2017). This idea has been conceptualized as territorial servitization, an economic activity intensifying the performance of regional economic structures (Sternberg \& Arndt, 2001), rendering the manufacturing industry more resilient to changes in the business environment (Camagni, 2002; Lafuente et al., 2010; Jacobs, Van Rietbergen, Atzema, Van Grunsven, \& Van Dongen, 2016). Territorial servitization pays attention to how service competencies create economic and social benefits within a focal territory (Lafuente et al. 2017; Vendrell-Herrero \& Wilson, 2017).

If the service competencies resulting from servitization processes get wellembedded in a regional industry cluster (Storper \& Walker, 1989), they may become 'locational assets' strengthening territorial competitiveness, innovativeness, and employment (Asheim \& Gertler, 2005; Stam, 2007). As an economic activity, territorial servitization may furthermore boost entrepreneurial activities in terms of new manufacturing and service companies. These new companies positively influence employment sustainability (Lafuente et al., 2017). Intensifying the performance of regional economic structures becomes increasingly important in regions which have experienced a decline in their manufacturing industries (Bailey \& De Propris, 2014).

Despite the emerging research, our understanding of a framework for territorial servitization remains modest. In particular, we lack insights into the mechanisms of how regions benefit in the industry life cycle from service competencies in the 
manufacturing industry. The present paper aims at filling this gap with a grounded theory approach which allows highlighting these mechanisms and developing the first framework in detail for the W2E industry.

\section{RESEARCH METHOD}

\subsection{Research setting}

To answer our research question, we selected multiple European regions such as Lower Saxony and Mecklenburg-Western Pomerania in Northern Germany, Midtjylland in Denmark, as well as the Basque country and Navarra in Northern Spain. In these regions, we investigated the wind-to-energy (W2E) industry. These regions incentivised the development of W2E technologies. They followed lead-market rationale (Beise \& Rennings, 2005), assuming that locally developed W2E technologies can later be exported. As a renewable energy sector, W2E has become strategically important for our selected regions.

The W2E industry basically entails three core activities, starting with component manufacturers (blades, gears, rotors, towers, etc.), wind turbine manufacturers, and wind turbine operators (farmers, utilities, and independent power producers [IPPS]) (Huenteler, Ossenbrink, Schmidt, \& Hoffmann, 2016). The W2E industry has experienced rapid growth, with an annual installed capacity of 100 Megawatts (MW) in 1990 and of 54,640 MW in 2016 (including 40,258 MW onshore and 14,384 MW offshore applications) (GWEC, 2017). Servitization processes in terms of extending the service offerings in each of the three value chain activities have become an integral part of the W2E industry and gradually changed the competence configurations in our regions.

\subsection{Data collection}


We attempted to answer our research question through qualitative research methods (Eisenhardt, 1989). Appendix A summarises our data sources. Altogether, we conducted 34 interviews between 2013 and 2016. We conducted 24 interviews with company representatives in senior management positions, as well as with 10 industry experts. Interview formats with the industry experts were quite similar to a Delphi method (Miller, 1993), whereas company interviews were aimed at being representative of servitization processes in the three core activities in the W2E industry.

The semi-structured interviews lasted between 60 and 90 minutes. We asked about servitization processes during the W2E industry life cycle, starting from the early '90s up to 2016. We facilitated a discussion on the emergence of regional benefits in the interviewees' own language, rather than using pre-defined constructs. Throughout the interviews, we used follow-up questions consistent with the narrative approach (Mishler, 1986) to gain deeper insights into the mechanisms between servitization processes in terms of extending service offerings, service competencies, and regional benefits.

To enhance the content validity, interviewees were asked to review the interview summaries. In addition, relevant secondary data (e.g. industry reports) were used to triangulate the primary interview data. This procedure allowed us to achieve theoretical saturation, that is, reaching a point where recurring themes for territorial servitization emerged (Bowen, 2008). Informants made comments and indicated their agreement with these summaries and on several occasions suggested small changes to increase conceptual clarity. Finally, we presented our preliminary results in a group discussion, thus confirming the regional benefits.

\subsection{Data analysis methods}


By following the guidelines of naturalistic inquiry (Lincoln \& Guba, 1985), we analysed our data inductively as we collected them. We began our analysis by identifying servitization processes (extending service offerings), service competencies and regional benefits in the data and grouping them into categories (open coding). For this analytical step, we identified first-order (Van Maanen, 1979) categories (i.e., terms and language appropriate to the level of understanding of the informants) whenever possible, or a simple descriptive phrase. We relied on a constant comparison of multiple informants over time in order to detect conceptual patterns among our categories (Strauss \& Corbin, 1998).

Along with developing first-order categories, we engaged in axial coding (Strauss \& Corbin, 1998), which entails searching for relationships between and among these categories and assembling them into second-order themes. We used a matching logic to classify and structure first-order categories and second-order themes across the various interviews. We then finally integrated the second-order themes into overarching dimensions that enabled us to develop a theoretical framework that linked the various phenomena on territorial servitization (e.g. servitization processes in terms of extending service offerings, service competencies, and regional benefits) (Nag et al., 2007). We looked specifically into regional benefits, which go beyond those discussed previously and provide useful conclusions for an initial territorial servitization framework (Gioia \& Pitre, 1990).

\section{$4 \quad$ FINDINGS}

\subsection{Emergent findings}

Figure 1 depicts the emergent data structure. Appendix B illustrates in more detail the structure and ordering of the data from specific, first-order categories used by informants to more general, researcher-induced second-order themes and overarching 
dimensions.

\begin{tabular}{|c|c|c|}
\hline $\begin{array}{l}\text { First-order categories } \\
\text { (Servitization processes) }\end{array}$ & $\begin{array}{l}\text { Second-order themes } \\
\text { (Service competences) }\end{array}$ & $\begin{array}{l}\text { Overarching dimensions } \\
\text { (Regional benefits) }\end{array}$ \\
\hline & Industry formation phase & \\
\hline $\begin{array}{l}\text { Component suppliers building up competences for } \\
\text { providing R\&D services }\end{array}$ & $\begin{array}{l}\text { Service competencies for providing R\&D services } \\
\text { in collaboration between component suppliers and } \\
\text { wind turbine manufacturers }\end{array}$ & $\begin{array}{l}\text { Efficient allocation of } \\
\text { technology resources }\end{array}$ \\
\hline $\begin{array}{l}\text { Wind turbine manufacturers offering services for } \\
\text { ensuring turbine functionality }\end{array}$ & $\begin{array}{l}\text { Competences for developing, promoting, and } \\
\text { delivering traditional after-sales services }\end{array}$ & \\
\hline $\begin{array}{l}\text { Wind turbine operators moving toward being self- } \\
\text { sufficient in practices for operating and maintaining } \\
\text { wind turbines }\end{array}$ & $\begin{array}{l}\text { Competences for operating and maintaining wind } \\
\text { turbines }\end{array}$ & \\
\hline & Growth phase & \\
\hline $\begin{array}{l}\text { Component suppliers offering services along the } \\
\text { entire value chain }\end{array}$ & $\begin{array}{l}\text { Co-specialization of competences for providing } \\
\text { services along the entire value chain (design, } \\
\text { construction, manufacturing, logistics etc). }\end{array}$ & Strengthening territorial competitiveness \\
\hline $\begin{array}{l}\text { Wind turbine manufacturers offering services for } \\
\text { ensuring turbine availability and productivity and } \\
\text { bundling services into customer-specific solutions }\end{array}$ & $\begin{array}{l}\text { Service competences for entering new } \\
\text { geographical W2E markets }\end{array}$ & Opening up new W2E markets \\
\hline $\begin{array}{l}\text { Wind turbine operators requesting customer- } \\
\text { specific solutions on achieving outcome-based } \\
\text { services (productivity levels) }\end{array}$ & $\begin{array}{l}\text { Co-creation of service competences for ensuring } \\
\text { certain productivity and availability levels }\end{array}$ & \\
\hline & Maturity phase & \\
\hline $\begin{array}{l}\text { Component suppliers optimizing and industrializing } \\
\text { service offerings through digital technologies }\end{array}$ & $\begin{array}{l}\text { Service competences for a broader product } \\
\text { portfolio }\end{array}$ & \\
\hline $\begin{array}{l}\text { Wind turbine manufacturers optimizing and } \\
\text { industrializing service offerings through digital } \\
\text { technologies } \\
\text { Wind turbine manufacturers transferring and } \\
\text { modifying service offering from onshore to offshore } \\
\text { wind parks and bundling services into customer- } \\
\text { specific solutions for offshore parks }\end{array}$ & $\begin{array}{l}\text { Service competences as a major motivation for } \\
\text { M\&A activities }\end{array}$ & $\begin{array}{l}\text { Raising the odds of securing employment } \\
\text { during consolidation period }\end{array}$ \\
\hline $\begin{array}{l}\text { Wind turbine operators requesting robust solutions } \\
\text { for offshore wind parks }\end{array}$ & $\begin{array}{l}\text { Service competences for planning, financing, } \\
\text { installing, operating, and maintaining offshore wind } \\
\text { parks }\end{array}$ & Enabling technological leaps \\
\hline
\end{tabular}

Figure 1: Framework on territorial servitization

The boxes on the left of Figure 1 show the first-order categories on servitization processes, along the core value-chain activities of component manufacturers, wind turbine manufacturers, and wind turbine operators. The concepts contained in the ovals show the integration of these first-order categories into second-order themes. These second-order themes represent service competencies, which change the territorial configuration of competencies. The right side of Figure 1 illustrates the overarching dimensions of regional benefits that emerged from the analysis.

Our interviews revealed that servitization processes in terms of extending the service offerings were an integral part of the W2E industry. The extensions of the service offerings have significantly changed the competence configurations in the 
regions throughout the industry's formation, growth, and maturity phases. The industry formation phase started in the early '90s and continued until 2000. During this phase, regional benefits in terms of two overarching dimensions, namely, employment generation and efficient allocation of technology resources, were observed. The growth phase preceded the industry formation phase and ended with the financial crisis in 2009. Opening up new W2E markets and strengthening territorial competitiveness are core regional benefits in this second phase. Subsequently, the industry moved to a maturity phase, in which product differentiation decreased and cost-based competition intensified. During this phase, raising the odds of securing employment and enabling technological leaps represent the regional benefits. In the next few sections, we will discuss each phase in more detail.

\subsection{Industry formation phase (1990-2000)}

The idea of the lead-market model led to three distinct servitization processes during the industry formation phase. First, component manufacturers intensified R\&D services to support turbine manufacturers in developing a dominant wind turbine architecture. Second, wind turbine manufacturers started to offer services for ensuring turbine functionality. Third, turbine operators developed practices for operating and maintaining the wind turbines. The underlying service competencies changed the competence configuration, which finally led to two regional benefits: enabling an efficient allocation of technology resources and generating employment opportunities.

Enabling an efficient allocation of technology resources: Competencies in R\&D services render the allocation of resources to the most promising W2E technologies more efficient. W2E technologies were still in a state of flux, limiting the emergence of a dominant product architecture (Huentler et al., 2016). Such a product (turbine) 
architecture would determine the design and configuration of components. Our data suggest, for example, that it was '...critical to anticipate whether to develop turbines using [components for] a constant and/or variable rotational speed'. Anticipating the most promising product architecture becomes an important regional asset in the industry formation phase.

In this situation, R\&D services lead to highly specialized competencies, which make the prediction of technology changes more reliable, mitigate the technology and investment risks, and progressively improve components. For example, considering the abovementioned technology choice on investing in constant and/or variable rotational speed, one participant suggested that R\&D competencies informed companies that '... even if initially ... constant speed looked like the dominant product design ... with $85 \%$ of the total capacity ... variable speed became the dominant approach'. As this statement suggests, sharing collaborative R\&D service competencies made regions more resilient to technology changes.

Generating employment opportunities: This second regional benefit results from the interplay of service competencies for ensuring turbine functionality and for operating and maintaining the wind turbines. The latter foster the establishment of a dominantuse design, which means that novel changes to servicing the turbines are no longer induced. In the early W2E industry, lead customers were farmers recognizing that agriculture is losing its economic significance (Garud \& Karnøe, 2003). As the following statement suggests, '...farmers ... were keen on becoming self-sufficient by producing electricity. ... They ... operate and maintain the wind turbines themselves. ...'. Lead customers specialized in operating and maintaining wind turbines. This led to a situation in which lead customers were no longer inducing novel changes to servicing the turbines. Such service competencies were turned into employment opportunities 
for lead customers. As new customers conformed with existing service practices, these opportunities occurred in our investigated regions but quickly reached neighbouring regions (e.g. Galicia and Andalusia in Spain, Schleswig-Holstein in Germany, as well as Syddanmark and Nordjylland in Denmark) and international markets.

Since customers specialized in operation and maintenance services, wind turbine manufacturers focussed only on competencies for ensuring turbine functionality through traditional after-sales services. This is consistent with the argument that the manufacturing industry initially is less attentive to services, since it still experiences uncertainty as to dominant technical characteristics (Cusumano et al., 2015). A participant characterized this initial phase as follows: '... wind turbine manufacturers were rather introverted, and less attentive to the service needs of customers...' Wind turbine manufacturers had the freedom to allocate more resources to technology development and (international) expansion. As one participant explained:

Without the need to invest in [operation and maintenance] services ... we could increase our international sales rapidly ... from the early start, $50 \%$ of the revenue came from ... other countries...

This rapid expansion made the W2E industry attractive and built the foundation for generating employment opportunities. For example, one participant argued that:

... companies producing wind turbines, blades, rotors, generators ... achieved attractive growth ... making these companies ... inspiring employers.

Altogether, servitization leads to the following regional benefits during the industry formation phase: (1a) enabling an efficient allocation of technology resources, and (1b) generating employment opportunities. 


\subsection{Growth phase (2001-2009)}

In the growth phase, lead customers no longer drive the demand for W2E technologies. Instead, IPPs and utilities, as well as fast-growing countries (e.g. Brazil, India, and China) emerged as W2E markets. Changes in the W2E industry entail three servitization processes. Wind turbine operators (IPPs and utilities) started to request advanced services. To do so, wind turbine manufacturers intensified services for ensuring the availability and productivity of wind turbines and for providing customerspecific solutions for entire wind parks. To succeed with such services, key component manufacturers of blades, rotors, generators, etc., began offering design, construction, and logistic services, which accumulated as co-specialized service competencies along the entire value chain. This co-specialization tied component suppliers more strongly to wind turbine manufacturers. These servitization processes yield two regional benefits: opening up new markets and strengthening territorial competitiveness.

Opening up new markets: At the beginning of the growth phase, there were initial signals pointing to a need for more sophisticated service competencies. One participant phrased it as follows:

Our wind turbines installed in the '90s were aging ... making maintenance procedures more complex. ... Customers were no longer willing to maintain the wind turbines themselves.

At the same time, utilities and IPPs, as new W2E markets, did not require single wind turbines but needed to ensure the productivity of entire wind parks. These parks function through long-term service-level agreements guaranteeing the availability of wind turbines and their components (Visnjic, Neely \& Jovanovic, 2018). Service 
competencies for ensuring such agreements became critical for entering these new markets. One participant argued as follows:

...services ... ensuring certain availability levels... were decisive... [for] successfully entering the utility market.

Accordingly, service competencies opened up such new markets, which soon represented a significant part of the total W2E revenue in one region. One participant substantiates this line of reasoning: 'By entering the utility market ... our sales multiplied by the factor 2.5 between 2004 and 2008 ...'

Whereas these W2E markets (utilities and IPPs) represented opportunities, the new international W2E market threatened regional economic activities in two ways. First, selling W2E technologies to emerging countries required locating competencies in these countries. This led to a more multi-locational configuration of competencies. Yet, with service competencies resulting from moving toward integrated design, construction, and logistic services, theses competencies became shared between manufacturers of wind turbines, blades, rotors, generators, etc. These shared and collaborative service competencies protected the regions from relocation of manufacturing activities. During the growth phase, the W2E industry thus invested in the international expansion of competencies but also kept the competence configuration within the home regions.

Second, growing W2E markets attracted incumbents from other industries. These incumbents entered the W2E industry through mergers \& acquisitions (M\&As). Such M\&As can put the manufacturing capacities and competencies in the home regions at risk because incumbents might relocate (offshore) critical competencies. An industry expert commented: 
When we saw a first wave of acquisitions, we feared that our region would lose highly specialized jobs because manufacturing capacity might be relocated ...

Such capacity relocations threaten employment since there are limits to a later reshoring of capacity back to the regions. Interestingly, our data suggests that incumbent companies did not in fact threaten the employment in the W2E industry's home regions. Instead, incumbents introduced critical service competencies to further advance the W2E industry. As a participant stated:

[When] General Electric [GE] and Siemens became interested in wind energy ... they had ... competencies for servicing ... other power generation and transmission [equipment] ... [introducing] these service competencies ... pushed the entire industry.

In addition, incumbents provided critical (service) competencies for entering new geographical markets (Brazil, China, and India). Their entry facilitated learning processes on service competencies, also leading to a situation in which all companies could develop the necessary service competencies for targeting new W2E markets (e.g. utility-scale wind parks, emerging countries). In particular, new service competencies were developed in that phase that were necessary for guaranteeing the availability and productivity of wind turbines and providing customer-specific solutions (. These service competencies opened up new W2E markets and strengthened employment in the home regions. As one industry expert suggested: '...employment [in the W2E industry] grew rapidly from a few thousands to 50,000 in Basque country and Navarra, and to 100,000 people in German regions in 2009'.

Strengthening competitiveness: The rapid growth of the W2E markets was interrelated with specializing in narrower sets of core competencies. These core competencies 
were observed to result increasingly from service competencies. For example, IPPs increasingly specialized in the service competencies necessary to plan, finance, operate, and maintain wind parks. Manufacturers similarly specialized in competencies for achieving certain outcomes (e.g. turbine productivity and availability). As one participant stated: '... we increasingly offered services guaranteeing availability and productivity levels of our turbines ...' Such services required component manufacturers to become specialized in servicing their critical components (e.g. blades, generators, or gearboxes) while also assisting manufacturers in maintaining their wind turbines. This integration of service competencies along the whole value chain further reinforced the need to spatially co-locate suppliers, turbine manufacturers, and service companies.

In addition, this integration strengthened territorial competitiveness by enabling new innovations, as well as quality and productivity improvements: As one participant stated:

'Together [with subcontractors for erecting the turbine and connecting it to the grid], we brought down the installation ... costs ... increasing the rate of return for our turbines ...'

Similar productivity improvements were found in production optimization services. New W2E markets (e.g., utilities, IPPs, and emerging countries) led to much larger production volumes, making it necessary to develop production-optimization services for coping with higher production volumes. These production optimization competencies became diffused among manufacturing companies relatively quickly, which further strengthened the competitiveness of the home regions. As one participant argued: 'Utilities look for high-quality turbines and are willing to pay a price premium for them... increased quality leads to sustainable competitive advantages'. Additionally, the increasingly integrated knowledge exchange during the service 
collaboration inspired new innovations (Kortmann \& Piller, 2016). As one participant stated:

By providing services to [wind parks operated by] utilities, we learned that many [wind park] sites do not have high wind-speeds. ... This inspired us to design a new wind turbine generation suitable for low- to mediumwind speed.

Such innovations and improvements in quality and productivity created a selfreinforcing feedback loop between manufacturing and service competencies, making the entire W2E industry in our regions more resilient to changes in the business environment during the growth phase and reinforcing their territorial competitiveness. This increasingly specialized and integrated competence portfolio of the W2E industry clusters became increasingly difficult for others to imitate.

Altogether, servitization leads to the following regional benefits in the growth phase: (2a) opening up new markets and (2b) strengthening territorial competitiveness (see Figure 1, Appendix B).

\subsection{Maturity phase (since 2009)}

In the maturity phase, the W2E industry continued with two servitization processes. First, component and turbine manufacturers continued integrating digital technologies into their service offerings and service competencies. Second, turbine manufacturers modified and then applied service competencies from onshore to offshore wind park applications. Accordingly, these servitization processes yield two new regional benefits: raising the odds for securing employment during the consolidation period and enabling technological leaps (see Figure 1 and Appendix B). 
Raising the odds of securing employment during the consolidation period: The maturity phase started with the financial crisis in 2009. Our regions experienced a significant sales drop, while competitors from emerging markets expanded their market share. One participant commented on the crisis as follows:

... there was a fear that the European industry would lose its pioneering role to Indian and Chinese competitors ...

Yet, our data reveals that by maintaining the emphasis on servitization, the European W2E industry could further increase its financial resilience. Augmenting products through optimized services made it possible to keep prices stable, whereas competitors were trying to cut them aggressively to gain market share. As one participants stated, these competitors deliberately targeted utilities and IPPs as important W2E markets: '.. advanced services enabled us to keep our market leader position in the utility market, and [through services] ... we were competitive enough to maintain prices, even during the financial crisis.'

The optimization of service offerings between utilities and turbine manufacturers enabled the latter to gain deeper insights into changes in customer requirements. The following participant statement suggests an emerging requirement for a platform strategy across a broader product portfolio: '[Through] availability and productivity solutions, ... we learned that ... we needed to be more flexible in terms of turbine sizes, quality levels, and lifetimes.'

These insights inspired the W2E industry to develop a modular platform approach with different turbine sizes, qualities, and lifetimes. High-quality products with a long lifetime were used to maintain competitive advantages in the utility market, whereas less durable products were promoted in emerging countries. Such platform approaches were vital, since sales in their home markets declined considerably in the maturity phase. For example, the Basque Country experienced a decline in the 
domestic demand for W2E technologies between 2009 and 2012. Broadening the product portfolio and also relying on medium quality and costs made it possible to secure and expand the sales volumes in emerging countries. For example, one Spanish turbine manufacturer found that about $70 \%$ of the order intake came from emerging markets. As an industry expert suggested: '... increasing sales volumes in emerging markets proved vital for our Spanish regions in coping with the financial crisis ... thus keeping the regional employment level relatively stable at around 70,000 jobs'.

Besides the introduction of modular platform approaches, competencies for utilizing digital technologies for optimizing the service offerings also kept employment within the region. As one participant argued:

... we now continuously monitor 16,000 turbines and provide ... optimisation services for them. Such services ... require highly experienced service engineers ... We ... locate these competencies in our headquarters.

Furthermore, the maturity phase led to a second wave of M\&As. These M\&A activities were not driven by incumbents entering the W2E industry anymore. Instead, companies across our regions merged under an increasing pressure for consolidation. Among others, these M\&A activities further integrated and optimized service offerings and continued the conversion of service competencies into core competencies. Typical examples include Siemens merging with Gamesan and Nordex with Acciona. Combining service competencies strengthened the overall market positions of the companies. Acciona, for example, contributed to the merger with valuable service competencies in developing wind park projects, which in turn generated a major share of Nordex's revenues from wind turbine installations in these parks. The second wave of M\&As thus indirectly further increased the odds of securing employment. 
Enabling technological leaps: Besides the financial crises, the maturity phase was also characterized by a major shift in technologies: the onshore technologies stagnated, while offshore technologies became increasingly important. Offshore wind parks operate in extreme conditions such as storms, severe humidity, and corrosion. Accordingly, one participant stated that: 'Installation, operational and maintenance costs are three times higher for offshore than for onshore solutions'. Thus, advanced service competencies were a precondition for embarking on the technological leap toward offshore technologies. Wind turbine manufacturers had to adapt and transfer service competences from onshore to offshore wind park applications. The W2E industry in the home regions with core competencies for servicing onshore wind parks had a first-mover advantage for providing the services necessary for offshore wind parks.

Again, servicing offshore wind parks generated valuable ideas which were subsequently converted into new W2E products, in turn improving offshore technologies. Turbines for high wind speed offshore sites and pitch-and-yaw regulators optimizing the rotational speed at any given wind speed are typical examples of such innovations. Interestingly, these innovations were not restricted to the existing W2E industry but also benefited other industries. Examples include the shipbuilding industry, in which companies specialized in tailor-made vessels in order to reduce the installation time for large offshore wind towers, or the IT industry, which provided proprietary communication solutions for offshore wind parks. A participant substantiated the latter: '... our onsite maintenance staff needs to communicate ... a firm ... [developed for] us a heavy-duty communication solution, which coped with the extreme temperatures and high levels of dust inside our turbines'.

Such innovations did not occur automatically but profited from insights into services, product architecture, and product components along the entire (offshore) 
wind park life cycle. These innovations also benefitted from an innovation culture and entrepreneurial tradition in the home regions, which had developed in previous rounds of innovation success. The home regions utilized their service competencies to make a leap into the offshore technologies. Managing this technology leap smoothly has further increased the employment levels in these regions. For example, an industry expert stated: '...the regions in Germany increased [both direct and indirect] employment in the W2E industry to up to 150,000 people in 2016'.

Altogether, servitization leads to the following regional benefits in the maturity phase: (3a) raising the odds of securing employment during the consolidation period and (3b) enabling technological leaps.

\section{IMPLICATIONS FOR ACADEMIC RESEARCH}

The findings make three distinct contributions to academic research. First, we reveal a grounded theory model on how servitization processes and service competencies in the W2E industry lead to regional benefits. In the industry formation phase, regional benefits are formed through the interplay of efficient allocation of technology resources (1a) and employment generation by following the lead-market model (1b). Opening up new W2E markets (2a) and strengthening territorial competitiveness (2b) are core regional benefits during the growth phase. In the maturity phase, raising the odds of securing employment during the consolidation period (3a) and enabling technological leaps were key regional benefits (3b).

Identifying these benefits extends previous contributions to territorial servitization which focused on employment, resilience, or start-up rates as territorial benefits (e.g. Lafuente et al., 2017; Kamp \& Ruiz de Apodaca, 2017; Vendrell-Herrero \& Wilson, 2017). In our work, the argument that servitization strengthens employment has been specified for each phase in the industry life cycle. In early phases, 
employment is generated through lead-customers developing service competencies, whereas in later phases, competencies related to accessing new markets and technologies played a key role. While some scales and construct descriptions on territorial servitization already exist (e.g. employment in new and/or existing manufacturing companies, new KIBS, number of manufacturing companies) (Aranguren, De La Maza, Parrilli, Vendrell-Herrero \& Wilson, 2017; Lafuente et al., 2017), the newly identified mechanisms could further advance the operationalization of these constructs.

Our findings also open new interfaces to industry life cycle theory. Our framework supports recent studies which argued that the regional benefits related to servitization processes differ systematically between various industry life cycle phases (Cusumano et al., 2015). Yet, what causes these differences remains underexplored in the literature. Our results identified various market- and technology-related life cycle dynamics that were not the focus of traditional life cycle theories (Huenteler et al., 2016; Peltoniemi, 2011). Additional research on the interface of servitization and life cycle perspectives is thus encouraged.

Second, our framework for territorial servitization can be linked to the debate on sustainability transitions (Markard, Raven, \& Truffer, 2012). The W2E industry is a 'cleantech' industry whose development dynamics depend on a broader sustainability transition in which fossil energy sources are replaced with renewable energy technologies (Geels et al., 2016). Our findings support recent transition studies which argued that the wind power industry develops spatially in a particularly 'sticky' transition trajectory (Binz \& Truffer, 2017). Yet, we provide a novel element to these theories in showing how service competencies further enhance spatial stability, as they provide lead companies with opportunities to profit repeatedly from a locally grown cluster structure. 
Third and finally, certain elements of our territorial servitization framework contribute to existing territorial innovation models (e.g. clusters, industrial districts, regional innovation systems) (Moulaert \& Sekia, 2003) and the discussion on regional development in business literature (e.g. KIBS, entrepreneurial role models, hightechnology regions, lead-market model, M\&A activities for regional development).

With regard to territorial innovation models, our results reveal that servitization processes are a significant and under-researched determinant of regional competitiveness and resilience. While the literature on territorial innovation models was criticised for having a 'productionist' and supply-side bias (Moulaert \& Sekia, 2003), our results show that service competencies are an important factor in explaining why certain industrial activities remain stuck in place (or not). Cluster initiatives and specialization strategies should thus more actively include a service competence perspective on employment and economic growth.

For the literature on regional development in business studies, the following findings stand out. Our emerging framework suggests that the concept of $K I B S$ should go beyond the simple distinction into service and manufacturing companies. Not only KIBS, but also servitization processes in manufacturing companies enhance the competitiveness of an industry in a certain territory, while at the same time competitiveness boosts servitization processes, facilitating the growth and resilience of the manufacturing industry (Gallouj, 2002).

The findings on the differences between dominant use and dominant product architecture design (Cusumano et al., 2015) contributes to the lead-market model. The former occurs relatively quickly and is driven by service practices diffused among initial customers. The diffusion of such service competencies means that employment generation is partly at the customers' locations, which can extend beyond the leadmarket territory. The lead-market territory benefits indirectly from the diffusion of 
service competencies, since it ensures a rapid expansion of the industry in the leadmarket and then into other territories.

This diffusion of service competencies resonates with the entrepreneurial role model of positive examples (Lafuente et al., 2007). Our findings suggest a need to apply this role model to the discovery of W2E opportunities. The entrepreneurial role model is important to establishing a dominant-use design. Thus, this entrepreneurial role model is an interesting perspective on understanding employment generation through diffusing service practices among customers.

The efficient allocation of technology resources can be embedded into the concept of industrial clusters, in which companies in the cluster specialize in different value chain activities (Boix \& Galletto, 2009; Fritsch \& Slavtchev, 2010). Service competencies play a vital role in these specialization processes (Cantner \& Graf, 2004). R\&D service competencies (Kohtamäki \& Partanen, 2016) ensure the efficient allocation of resources and are intertwined with cultural homogeneity, congruity, and proximity among companies within the W2E industry (Becattini, 2015; Boschma, 2005). An intimate knowledge exchange within industrial clusters makes it easier to navigate through the state-of-flux period in the industry formation phase (Anderson \& Tushman, 1990; Garud \& Karnøe, 2003; Klepper, 1997).

Opening up new W2E markets and raising the odds of securing employment offer interesting insights into the role of $M \& A$ activities for regional development (Colombo \& Turati, 2014). Enabling technology leaps contributes to the debate on high-technology regions. Service competencies can be interpreted as an example of collective learning and networks, which are smoothing technology leaps. Therefore, service competencies are vital for technology development in innovative hightechnology regions (Eskelinen, Hannibalsson, Malmberg, Maskell, \& Vatne, 2002; Longhi, 1999). 
Improving territorial competitiveness through servitization processes (Camagni, 2002) can be embedded into a general discussion of relocating economic activities (Andersen, 2006; Kinkel, 2012). Our findings suggest that service competencies unfolding through servitization processes onto suppliers moving toward design, construction, and logistic services hinder the relocation of manufacturing activities (Bailey \& Propris, 2014). In addition, strengthening territorial competitiveness through servitization processes leading to quality and productivity improvements and innovation can be embedded into the concept of innovation in industrial districts (Boix \& Galletto, 2009).

\section{IMPLICATIONS FOR POLICYMAKERS}

The multi-faceted regional benefits of servitization processes should be considered by policymakers, and the current strengths and weaknesses in industry development programs assessed in this context. Some of the benefits identified in the W2E case somewhat contradict common policy practice. For example, support strategies should not only focus on servitization processes for wind turbine manufacturers but also on component manufacturers and windfarm operators in upstream and downstream segments of the value chain. Supporting the creation of R\&D services that are shared between component and wind turbine manufacturers might facilitate the emergence of a dominant design for the product architecture. Attention should also be devoted to achieving a dominant-use design and on diffusing it among customers, since this allows companies to grow and internationalize more rapidly.

Our case showed that policymakers should not generally restrict the entrance of incumbent companies into a newly emerging industry. Instead, they should assess whether such companies can provide critical service competencies for opening up new markets and supporting innovation in the industry. 


\section{$7 \quad$ LIMITATIONS AND DIRECTIONS FOR FUTURE RESEARCH}

This paper inductively explores the mechanisms linking servitization processes, service competencies, and regional benefits, rather than testing them deductively. This means that we do not claim statistical generalizability of our findings but analytical generalizability of the derived framework. The description of the key elements in our framework for territorial servitization is intended to inform other researchers who can further evaluate our findings' relevance to other industries and/or regions.

As such, future research should take our framework as a point of departure for replicating and extending the findings in other regional and sectorial contexts. Crosscomparing the similarities and differences in servitization processes, service competencies and regional benefits through cross-industry studies could lead to a new taxonomy of industries and their related territorial servitization dynamics. Once such taxonomy has been substantiated with additional qualitative data; a cross-sectional analysis of quantitative data for testing the findings seems advisable.

\section{CONCLUSIONS}

The theoretical starting point of the study was the missing links between servitization processes, service competencies, and regional benefits. The emerging framework for territorial servitization developed and justified empirically in this paper highlights how servitization processes and service competencies lead to regional benefits. Our study of the W2E industry showed that the servitization processes and service competencies finally generated regional benefits. We suggest that this overall emerging framework can be linked to theoretical perspectives such as sustainability transitions, KIBS, and industry life cycles. In addition, elements of the framework should be embedded into concepts such as the lead-market model, entrepreneurial role models, industrial 
clusters, high-technology regions, and M\&A activities for regional development. Our findings should motivate both academics and practitioners to pursue the mechanisms behind servitization processes, service competencies, and regional benefits as crucial means of understanding territorial servitization.

\section{REFERENCES}

Andersen, P. H. (2006). Regional clusters in a global world: Production relocation, innovation, and industrial decline. California Management Review, 49(1), 101122.

Anderson, P., \& Tushman, M. L. (1990). Technological discontinuities and dominant designs: A cyclical model of technological change. Administrative Science Quarterly, 35(6), 604-633.

Aranguren, M. J., De La Maza, X., Parrilli, M. D., Vendrell-Herrero, F., \& Wilson, J. R. (2014). Nested methodological approaches for cluster policy evaluation: An application to the Basque Country. Regional Studies, 48(9), 1547-1562.

Asheim, B. T., \& Gertler, M. S. (2005). Regional innovation systems and the geographical foundations of innovation. The Oxford handbook of innovation, 291-317.

Bailey, D., \& De Propris, L. (2014). Manufacturing reshoring and its limits: The UK automotive case. Cambridge Journal of Regions, Economy and Society, 7(3), 379-395.

Baines, T., Ziaee Bigdeli, A., Bustinza, O. F., Shi, G., Baldwin, J. S., \& Ridgway, K. (2017). Servitization: Revisiting the state-of-the-art and research priorities. International Journal of Operations \& Production Management, 37(2), 256-278. 
Beise, M., \& Rennings, K. (2005). Lead markets and regulation: A framework for analyzing the international diffusion of environmental innovations. Ecological Economics, 52(1), 5-17.

Becattini, G. (2015). Beyond geo-sectoriality: The productive chorality of places. Investigaciones Regionales, 32(1), 31-41.

Binz, C., \& Truffer, B. (2017). Global Innovation Systems-a conceptual framework for innovation dynamics in transnational contexts. Research Policy 64(7), 12841298.

Boix, R., \& Galletto, V. (2009). Innovation and industrial districts: A first approach to the measurement and determinants of the I-district effect. Regional Studies, 43(9), 1117-1133.

Boschma, R. (2005). Proximity and innovation: A critical assessment. Regional Studies, 39(1), 61-74.

Bowen, G. (2008). Naturalistic inquiry and the saturation concept: A research note. Qualitative Research, 8(1), 137-152.

Cantner, U., \& Graf, H. (2004). Cooperation and specialization in German technology regions. Journal of Evolutionary Economics, 14(5), 543-562.

Camagni, R. (2002). On the concept of territorial competitiveness: Sound or misleading? Urban Studies, 39(13), 2395-2411.

Colombo, L. V., \& Turati, G. (2014). Why do acquiring banks in mergers concentrate in well-developed areas? Regional development and mergers and acquisitions (M\&As) in banking. Regional Studies, 48(2), 363-381.

Cusumano, M. A., Kahl, S. J., \& Suarez, F. F. (2015). Services, industry evolution, and the competitive strategies of product firms. Strategic Management Journal, 36(4), 559-575. 
Davies, A. (2004). Moving base into high-value integrated solutions: A value stream approach. Industrial and Corporate Change, 13(5), 727-756.

den Hertog, P. (2000). Knowledge-intensive business services as co-producers of innovation. International Journal of Innovation Management, 4(4), 491-528.

Eggert, A., Hogreve, J., Ulaga, W., \& Muenkhoff, E. (2011). Industrial services, product innovations, and firm profitability: A multiple-group latent growth curve analysis. Industrial Marketing Management, 40(5), 661-670.

Eisenhardt, K. M. (1989). Building theories from case study research. Academy of Management Review, 14(4), 532-550.

Eskelinen, H., Hannibalsson, I., Malmberg, A., Maskell, P., \& Vatne, E. (2002). Competitiveness, localised learning and regional development: Specialization and prosperity in small open economies (Vol. 14). London: Routledge.

Fang, E., Palmatier, R. W., \& Steenkamp, J. B. E. (2008). Effect of service transition strategies on firm value. Journal of Marketing, 72(5), 1-14.

Fritsch, M., \& Slavtchev, V. (2010). How does industry specialization affect the efficiency of regional innovation systems? The Annals of Regional Science, 45(1), 87-108.

Gallouj, F. (2002). Knowledge-intensive business services: Processing knowledge and producing innovation. In J. Gadrey \& F. Gallouj, (Eds.), Productivity, innovation and knowledge in services: New economic and socio-economic approaches, (pp. 256-284).

Garud, R., \& Karnøe, P. (2003). Bricolage versus breakthrough: Distributed and embedded agency in technology entrepreneurship. Research Policy, 32(2), 277-300. 
Geels, F.W., Kern, F., Fuchs, G., Hinderer, N., Kungl, G., Mylan, J., Neukirch, M., \& Wassermann, S. (2016). The enactment of socio-technical transition pathways: A reformulated typology and a comparative multi-level analysis of the German and UK low-carbon electricity transitions (1990-2014). Research Policy, 45 (4), 896-913.

Gioia, D. A., \& Pitre, E. (1990). Multiparadigm perspectives on theory building. Academy of Management Review, 15(4), 584-602.

GWEC. (2017). Global Wind Energy Council Reports. Retrieved from http://gwec.net/publications/global-wind-report-2/

Huenteler, J., Ossenbrink, J., Schmidt, T.S., \& Hoffmann, V.H. (2016). How a product's design hierarchy shapes the evolution of technological knowledge-evidence from patent-citation networks in wind power. Research Policy 45(6), 11951217.

Huenteler, J., Schmidt, T., Ossenbrink, J., \& Hoffmann, V. (2016). Technology lifecycles in the energy sector-technological characteristics and the role of deployment for innovation. Technological Forecasting \& Social Change 104, $102-121$.

Jacobs, W., Van Rietbergen, T., Atzema, O., Van Grunsven, L., Van Dongen, F. (2016). The impact of multinational enterprises (MNEs) on knowledge-intensive business services (KIBS) start-ups: Empirical evidence from the Dutch Randstad. Regional Studies, 50(4), 728-743.

Kamp, B., \& Ruiz de Apodaca, I. (2017). Are KIBS beneficial to international business performance: Evidence from the Basque Country. Competitiveness Review: An International Business Journal, 27(1), 80-95.

Kinkel, S. (2012). Trends in production relocation and backshoring activities: Changing patterns in the course of the global economic crisis. International Journal of 
Operations \& Production Management, 32(6), 696-720.

Klepper, S. (1997). Industry life cycles. Industrial and Corporate Change, 6(1), 145182.

Kohtamäki, M., \& Partanen, J. (2016). Co-creating value from knowledge-intensive business services in manufacturing firms: The moderating role of relationship learning in supplier-customer interactions. Journal of Business Research, 69(7), 2498-2506.

Kortmann, S., \& Piller, F. (2016). Open business models and closed-loop value chains:

Redefining the firm-consumer relationship. California Management Review, 58(3), 88-108.

Lafuente, E., Vaillant, Y., \& Rialp, J. (2007). Regional differences in the influence of role models: Comparing the entrepreneurial process of rural Catalonia. Regional Studies, 41(6), 779-796.

Lafuente, E., Vaillant, Y., \& Serarols, C. (2010). Location decisions of knowledgebased entrepreneurs: Why some Catalan KISAs choose to be rural? Technovation, 30(11), 590-600.

Lafuente, E., Vaillant, Y., \& Vendrell-Herrero, F. (2017). Territorial servitization: Exploring the virtuous circle connecting knowledge-intensive services and new manufacturing businesses. International Journal of Production Economics, 192, 19-28.

Lincoln, Y. S., \& Guba, E.G. (1985). Naturalistic inquiry. Beverly Hills, CA: Sage.

Longhi, C. (1999). Networks, collective learning and technology development in innovative high technology regions: The case of Sophia-Antipolis. Regional Studies, 33(4), 333-342.

Markard, J., Raven, R., \& Truffer, B. (2012). Sustainability transitions: An emerging field of research and its prospects. Research Policy, 41(6), 955-967. 
Matthyssens, P., \& Vandenbempt, K. (2008). Moving from basic offerings to valueadded solutions: Strategies, barriers and alignment. Industrial Marketing Management, 37(3), 316-328.

Menzel, M., \& Fornahl, D. (2009). Cluster life cycles-dimensions and rationales of cluster evolution. Industrial and Corporate Change, 19(1), 205-238.

Miller, M.M. (1993). Enhancing regional analysis with the Delphi method. The Review of Regional Studies, 23(2), 191.

Mishler, E.G. (1986). Research interviewing: Context and narrative. Cambridge, MA: Harvard University Press.

Moulaert, F., \& Sekia, F., 2003. Territorial innovation models: A critical survey. Regional Studies, 37(3), 289-302.

Muller, E., \& Zenker, A. (2001). Business services as actors of knowledge transformation: The role of KIBS in regional and national innovation systems. Research Policy, 30(9), 1501-1516.

Nag, R., Corley, K. G., \& Gioia, D. A. (2007). The intersection of organizational identity, knowledge, and practice: Attempting strategic change via knowledge grafting. Academy of Management Journal, 50(4), 821-847.

Neely, A. (2008). Exploring the financial consequences of the servitization of manufacturing. Operations Management Research, 1(2), 103-118.

Oliva, R., \& Kallenberg, R. (2003). Managing the transition from products to services. International Journal of Service Industry Management, 14(2), 160-172.

Peltoniemi, M. (2011). Reviewing industry life-cycle theory: Avenues for future research. International Journal of Management Reviews, 13(4), 349-375.

Saul, C. J., \& Gebauer, H. (2018). Born solution providers-dynamic capabilities for providing solutions. Industrial Marketing Management. Retrieved from https://doi.org/10.1016/j.indmarman.2018.01.007 
Stam, E. (2007). Why butterflies don't leave: Locational behavior of entrepreneurial firms. Economic Geography, 83(1), 27-50.

Sternberg \& Arndt, 2001

Storbacka, K. (2011). A solution business model: Capabilities and management practices for integrated solutions. Industrial Marketing Management, 40(5), $699-711$.

Storper, M., \& Walker, R. (1989). The capitalist imperative - territory, technology, and industrial growth. New York: Basil Blackwell.

Strambach, S. (2008). Knowledge-Intensive Business Services (KIBS) as drivers of multilevel knowledge dynamics. International Journal of Services Technology and Management, 10(2-4), 152-174.

Strauss, A., \& Corbin, J. (1998). Basics of qualitative research: Procedures and techniques for developing grounded theory.

Truffer, B., \& Coenen, L. (2012). Environmental innovation and sustainability transitions in regional studies. Regional Studies, 46(1), 1-21.

Vandermerwe, S., \& Rada, J. (1988). Servitization of business: Adding value by adding services. European Management Journal, 6(4), 314-324.

Van Maanen, J. (1979). The fact of fiction in organizational ethnography. Administrative Science Quarterly, 24, 539-550.

Vendrell-Herrero, F., \& Wilson, J. R. (2017). Servitization for territorial competitiveness: Taxonomy and research agenda. Competitiveness Review: An International Business Journal, 27(1), 2-11.

Visnjic, I., Neely, A., \& Jovanovic, M. (2018). The path to outcome delivery: Interplay of service market strategy and open business models. Technovation. https://doi.org/10.1016/j.technovation.2018.02.003 
Visnjic Kastalli, I. \& Van Looy, B. (2013). Servitization: Disentangling the impact of service business model innovation on manufacturing firm performance. Journal of Operations Management, 31(4), 169-180. 


\section{APPENDIX}

Appendix A: Overview of the interview partners

\begin{tabular}{|c|c|c|}
\hline $\begin{array}{l}\text { Interview } \\
\text { number }\end{array}$ & Organizational function of the participant & Company and position in the value chain \\
\hline & Participants from companies (functions) & \\
\hline 1 & Member of management team & $\begin{array}{l}\text { Supplier for vibration systems, structural mechanics, } \\
\text { acoustics and emission control systems }\end{array}$ \\
\hline 2 & Sales manager & Supplier of power transmission systems \\
\hline 3 & Vice president sales & Supplier of pitches and gears \\
\hline 4 & Head of R\&D & Supplier of heavy duty hydraulics \\
\hline 5 & Key account manager & Supplier of vibration monitoring systems \\
\hline \multirow[t]{2}{*}{6,7} & General manager & Supplier of rotor blades \\
\hline & Head of service business & \\
\hline 8,9 & $\begin{array}{l}\text { Service business development manager } \\
\text { Solution director }\end{array}$ & Wind turbine manufacturer \\
\hline \multirow[t]{2}{*}{10,11} & Sales director for solutions & Wind turbine manufacturer \\
\hline & Service business manager & \\
\hline 12 & CEO (Chief Executive Officer) & Wind turbine manufacturer \\
\hline 13 & Sales and Service leader & Wind turbine manufacturer \\
\hline 14 & Sales director for solutions & Wind turbine manufacturer \\
\hline 15 & Director customer service (Europe) & Wind turbine manufacturer \\
\hline \multirow[t]{2}{*}{16,17} & Head of wind park operation & Wind park developer and operator \\
\hline & General manager, operation \& maintenance & \\
\hline 18 & General manager, wind park development & Public utility operating wind parks \\
\hline 19 & Director of wind energy & $\begin{array}{l}\text { Business unit in a Wind-to-Energy and Solar energy } \\
\text { specialist, Wind park operator }\end{array}$ \\
\hline 20 & Technical support for wind parks & Wind park operator \\
\hline \multirow[t]{2}{*}{21} & Regional sales manager & Independent power producers / wind park operator \\
\hline & Wind park specialist & \\
\hline 22 & Head of wind power & $\begin{array}{l}\text { Renewable energy business unit in a public utility, Wind } \\
\text { park operator }\end{array}$ \\
\hline \multirow[t]{4}{*}{23,24} & Wind park manager & Multinational electric utility, Wind park operator \\
\hline & Account manager & \\
\hline & $\begin{array}{l}\text { Participating industry experts (function and } \\
\text { organization description) }\end{array}$ & \\
\hline & Function of the participant & Organization \\
\hline 25 & Team leader offshore activities & $\begin{array}{l}\text { Organization for promoting and advocating offshore } \\
\text { activities }\end{array}$ \\
\hline 26 & Member advisory board & Danish Association on wind energy \\
\hline 27 & Director & German Wind Energy Association \\
\hline \multirow[t]{2}{*}{28} & Vice president & Offshore Wind Working Group in the German Wind \\
\hline & & Energy Association \\
\hline 29 & Account manager (Europe) & Global Wind Energy Council \\
\hline 30 & Director & WindEurope \\
\hline 31 & Director & Asociación Empresarial Eólica (AEE) \\
\hline 32 & Director & Denmarks Vindmōlleforening (Danish Wind Turbines \\
\hline & & Owner Association) \\
\hline 33 & Director & Vindmølleindustrien: Danish Wind Industry Association \\
\hline 34 & Leader manufacturing association & Spanish Wind Energy Association \\
\hline
\end{tabular}




\section{Appendix B: Representative quotes and archival entries underlying second- order themes.}

\section{Theme 1a: Efficient allocation of technology resources}

Second-order themes First-order categories: Selective evidence from the interviews (interview quotes) and secondary data

\begin{tabular}{|c|c|c|}
\hline $\begin{array}{l}\text { Service competencies for } \\
\text { providing R\&D services } \\
\text { in collaboration between } \\
\text { component suppliers and } \\
\text { wind turbine } \\
\text { manufacturers }\end{array}$ & - & $\begin{array}{l}\ldots \text { it was critical to anticipate whether to develop turbines using } \\
\text { constant and/or variable rotational speeds. ... it looked like that } \\
\text { constant speed would become the dominant product design, since the } \\
\text { percentage increased from } 65 \% \text { to } 75 \% \text {. However, some years later, } \\
\text { only } 15 \% \text { of wind turbines relied on a constant rotational speed. With } \\
85 \% \text { of the total capacity, variable speed became the dominant } \\
\text { design. } \\
\text { In } 1993,81 \% \text { of the generators were induction generators and } 18 \% \\
\text { synchronous generators. In } 2003 \text {, these generator types were reduced } \\
\text { to } 51 \% \text { and } 49 \% \text { of the generators were now doubly fed.... R\&D } \\
\text { services played an essential role in predicting generator } \\
\text { development... } \\
\text { R\&D collaboration with suppliers helped us to predict the changes in } \\
\text { the aerodynamic control systems... initially, } 70 \% \text { of all aerodynamic } \\
\text { control systems were stalls, and } 30 \% \text { were pitches. Ten years later, } \\
\text { only } 14 \% \text { were stalls and } 86 \% \text { were pitches... } \\
\text { In the } 90 \text { s, wind turbines became much larger... Despite rapid growth, } \\
\text { developing larger wind turbines stretched the R\&D resources in the } \\
\text { entire industry... Thus, R\&D collaborations between suppliers and } \\
\text { wind turbine manufacturers were important... Collaborations improved } \\
\text { the prediction of emerging dominant product designs } \\
\text { Service practices were quickly shared among customers } \\
\text { Our customers quickly learned how to operate and maintain the wind } \\
\text { turbines }\end{array}$ \\
\hline
\end{tabular}

Theme 1b: Employment generation

Competencies for
operating and
maintaining wind
turbines

Competences for developing, promoting, and delivering traditional after-sales services
- Our initial customers were farmers who were keen on becoming selfsufficient, producing their own electricity

- Customers wanted to service the wind turbines themselves.

- Regional policy makers incentivized wind turbine investments, because it created employment opportunities in the region

- Without the need to invest in services, we could increase our international sales rapidly ... from the early start, $50 \%$ of revenue came from our home country and $50 \%$ from other countries...

- Since we did not initially have to invest into services, we could become profitable faster.

- Our industry had grown driven by peaks in oil and gas prices, efforts to reduce $\mathrm{CO} 2$ emissions and to achieve energy self-sufficiency... focusing on products allowed us to rapidly internationalize

- Since the early start, companies producing wind turbines, blades, rotors, generators and so on, achieved attractive international and domestic growth...

- We could keep the manufacturing capacity in our region, since all activities in the value chain were closely linked through exchanging services.

- Service competences played a key role in making manufacturing

\author{
capacities stick to our region
}

Close ties for service competences hinder the relocation (offshore) of manufacturing capacities 
Theme 2a: Opening up new W2E markets

Service competencies for entering new geographical W2E markets
Co-creation of service competences for entering new geographical markets
- IPPs wanted us to support them in conducting wind measurements and in operating and maintaining the turbines, and in assuring the grid connections.

- Utilities entering the wind-to-energy market demanded long-term service agreements and turnkey solutions.

- Advanced services helped us to tap successfully into the IPP and public utility segment.

- Thanks to being able to provide services for these new customer segments, we could increase sales between 2004 and 2008 from 49 to 122 GigaWatt).

- To win this battle for growth, the services we provided to our early customers became decisive.... We learned from maintaining these older turbines and leveraged these lessons into maintenance services for new customers...

- Service competences opened up the new segments ... These segments quickly represented $58 \%$ of total revenue

- When we saw a first wave of acquisitions, we feared that our region would lose highly-specialized jobs, because production capacity might be relocated ...

- General Electric and Siemens became interested in wind energy.... but wind was just one of the energy segments .... what was important was that they had critical competences for servicing equipment in the oil and gas industry, and other power generation and transmission segments. Theses service competences helped them to enter the wind industry....

- The service competences brought in by these firms pushed the entire industry ... other firms also quickly expanded their service competences.

- General Electric (GE) acquired Enron as it faced bankruptcy securing the future of Enron capacity in Germany and the United States. As a new business division, GE Wind invested in competences making the Enron acquisition one of the major wind turbine players. Germany, as Enron's focal territory, benefited from the acquisition through securing employment and supplier competences.

- When Suzlon took over RePower, many people feared that the Indians would replace away German engineering skills... however, RePower went through a couple of crises together with Suzlon... nevertheless, RePower could retain a strong position by protecting its service competences and intellectual property. ... today, RePower has almost doubled its employment...

- We specialized in competences for providing four solutions: simple turbine supply, supply and installation, services and turnkey solutions... These service competences reduced the risk of relocation.

- .... we offer advanced availability and productivity solutions... the competences could not be relocated.

- Our wind turbines installed in the 1990s were aging... making maintenance procedures more complex. ... Customers were no longer willing to maintain the wind turbines themselves.

- There was a need to develop new service competences

- These more complex maintenance procedures were increasingly beyond our customer competences... Customers wanted to have more service support. 
Co-specialization of competences for providing services along the entire value chain (design, construction, manufacturing, and logistic services)
- ... during the construction phase, we deliver the turbine to the customers. Customers have specialized subcontractors for erecting the turbine and connecting it to the grid.

- Availability solutions guarantee that the turbine would rotate for a certain amount of time per year. Productivity solutions ensure that the turbine produces a certain amount of energy per year... competences for such solutions strengthen our regions... competences were highly embedded in our value chain.

- Utilities look for high-quality durable turbines and are willing to pay a price premium for them... This pushed our industry and led to sustainable competitive advantages and attractive profitability, which in turn enabled the industry to increase technology advantages.

- Utilities calculate the long-term effects of investing in wind on their entire energy generation portfolio. This long-term perspective pushed us to improve our turbine quality, including the quality of all suppliers. Utilities were willing to pay a price premium for such high-quality products, which gave us a considerable competitive advantage, and improved our profitability.... This enabled us to invest more into innovations for maintaining our technology advantages.

- By collaborating with utilities, we learned that many sites do not have high wind-speeds.... We designed a new wind turbine suitable for lowto medium wind speed.

- In our collaboration with utilities, we learned that it is much easier to get building permits for wind parks, if wind turbines do not produce too much noise... We developed a new wind turbine suitable for low- to medium wind speed and for operating within a low decibel range.

\section{Theme 3a: Raising the odds of securing employment during consolidation period}

\author{
Service competencies for \\ a broader product \\ portfolio
}

- When we started to offer availability and productivity solutions, ... we needed to be flexible in terms of turbine sizes, quality levels and lifetimes.

- By relying on medium as opposed to high quality and costs, Gamesa tapped successfully into emerging markets and at the same time kept a strong hold on its domestic Spanish market. In 2016, 71\% of Gamesa's order intake came from emerging markets such as China, India, and Latin America. Even producing most of the turbines in China, India, and Brazil, Gamesa did not reduce employment in Spain. Instead, some employments changed from production to services, as Gamesa started to serve its installed capacity.

- ... we are the most international wind turbine producer, with production facilities in eight countries. We also offer a variety of turbines sizes and lifetimes... One turbine is produced, for example, completely in China and sold there exclusively. ... we sustained employment in our home country... and simply strengthened the competitive advantages of offering less advanced turbines for emerging markets.

- In 2010, there was fear that the European industry would lose its pioneering role to Chinese competitors .... Chinese Goldwind, for example, nearly tripled its revenue between 2008 and 2010 ... while European companies struggled financially.

- The financial crisis accentuated changes in the customer mix, and led to a few large utilities dominating the market.

- During the financial crisis, of course, some customers looked with interest at lower quality turbines, but were discouraged, as banks place a high-risk premium on such turbines. Most turbines produced in emerging markets are still sold in local markets and not in Europe.

- ... servitization enabled us to tap into the utility segments and based on that we were competitive enough to keep prices even during the financial crisis. 
Competencies for utilizing technologies in the service delivery

Service competencies as a major motivation for $M \& A$ activities
- The financial crisis led to consolidation in terms of forcing small customers out of the market with large utilities with stronger cash flows taking over their assets.

- ... servitisation enabled us to tap into the utility segments and based on that, we were competitive enough to keep prices even during the financial crisis. We are the Mercedes of the wind industry.

- “... we now continuously monitor 16 '000 turbines and provide ... optimization services for them. Such services ... require highly experienced service engineers... We ... locate these competencies in our headquarters.

- Siemens merging with Gamesan, and Nordex with Acciona. In such M\&As, service competences played a key role that the integration of these companies strengthens the overall market position. Acciona, for example, contributed to the merger with valuable service competences on developing new wind park projects, which in turn now generates a major share of Nordex revenues on wind turbines installed in these parks.

\section{Theme 3b: Enabling technological leaps}

Service competencies for planning, financing, installing, operating, and maintaining offshore wind parks
- In offshore, the turbine accounts only for $45 \%$ of the total cost, the rest is installing underwater cables, connecting the turbines ... Installation, operation and maintenance costs are three times higher for offshore than for onshore solutions.

- We developed a 3.6 MW turbine with a rotor diameter of 104 meters and a swept area of 8,495 square meters. The turbine was designed specifically for high-speed offshore sites.

- R\&D services (collaboration) to push offshore technologies was observed for pitch-and-yaw regulators. The pitch adjusts the blade's angel of "attack" leading to optimized rotational speed and lift-to-drag ratio at any given wind speed. Yawn control keeps the turbine facing the wind.

- R\&D services (collaboration) to push offshore technologies were also observed for active vibration damping, which reduces tower oscillation, resulting in greater drive train reliability, which would ultimately reduce maintenance costs and increase turbine lifetime.

- Service costs are three times higher for offshore than for onshore and highlight why service competences for operating and maintaining the product became critical.

- New firms specializing in tailor-made vessels to bring down the installation time for large offshore wind parks

- Our onsite maintenance staff needs to communicate ...but mobile telephones had limited coverage in these offshore areas, and were not very robust... so we were very happy when a new firm offered us a heavy-duty communication solution which coped with extreme temperatures and high levels of dust inside these turbines. 